\title{
Uncelebrated Sports Officials in the Middle East \& Africa
}

\author{
Nnamdi O. Madichie, PhD \\ Bloomsbury Institute London
}

While research shows that investment in sports has started shifting from the North to South and West to East, it has been observed that the latter has been more active than the former as far as sportsrelated activity is concerned. This is especially the case with popular sports such as football where Middle East investments have been active from outright team purchases (e.g., Manchester City and Paris Saint Germain), stadium naming rights (Etihad Stadium and Emirates Stadium), sponsorships (FC Barcelona/Qatar Airways), and the prized hosting of the 2022 FIFA World Cup in Qatar. In all these, however, the regions have had very limited, if any, impact in terms accredited officialdom. This study highlights this a potential area for research with implications for Sports Management in particular, and Business \& Management more broadly.

\section{Introduction}

While research shows that investment in sports has started shifting from the West to the East (including geographic areas such as the Middle East and China), it has been observed that the former has been more active than the latter as far as sports-related activity is concerned. This is especially the case with popular sports such as football where Middle East investments have been active from outright team purchases (e.g., Manchester City and Paris Saint Germain), stadium naming rights (Etihad Stadium and Emirates Stadium), sponsorships (FC Barcelona-Qatar Airways), and the prized hosting of the 2022 FIFA World Cup in Qatar. However, there have been other notable sports-related activity especially in relation to Aquatics (all water sports including swimming and diving), Cricket, and Rugby in the Middle East.

There have been debates on an arguably range of "irrational" sports investments in Cricket where the Pakistani diaspora in the Middle East have been at the center in places such as the United Arab Emirates (UAE), with the Emirate of Sharjah playing a central role in hosting the sport on a major scale; and in Rugby, which is more popular in neighboring Dubai where mainly British athletes have been at the forefront of the sport in its Dubai Rugby 7evens ground. ${ }^{1}$ This study seeks to rearticulate some of the trends, attitudes, behaviors, and changing configuration of sports investments in the Middle East, including participation, management/marketing, and the policy implications of these.

Following this opening section, the theoretical considerations, drawing upon the limited literature on the subject, are undertaken in the second section. This is followed by a discussion on the practical considerations highlighting the sports structure in the region of interest, signposting the workings of the Olympic Council of Asia (OCA), and the respective National Olympic Committees (NOCs) - Asian Football Confederation (AFC), and any interactions between these bodies. Anecdotal evidence of the limited representation of

\footnotetext{
${ }^{1}$ Nnamdi O. Madichie, “Ode to a 'Million Dollar' Question: Does the Future of Football Lie in the Middle East?" Management Decision 51, no. 9 (2013): 1839-60; Nnamdi O. Madichie, "Professional Sports: A New," The Marketing Review 9, no. 4 (2009): 301-18; Nnamdi Madichie and Vanessa Ratten, "Manifestations of Professional Sports in an Unfamiliar Terrain? Insights from Cricket \& Rugby in the UAE," paper presentation, the 23 ${ }^{\text {rd }}$ European Association for Sport Management (EASM) Conference, Dublin, Ireland, 9-12, September, 2015, www.easm.net/download/2015/easm2EASM-2015-1-450.pdf.
} 
sports officials of international standing/repute from the Middle East and North African (MENA) region is also provided. The study concludes with a range of implications on the need to develop, manage/train, communicate, and celebrate sports officials in the region.

\section{Theoretical Considerations}

A search of the literature on the topic revealed two recent $\mathrm{PhD}$ theses examining the role of Middle Eastern sports officials and the emergence of international umpires, referees, and other sports officials from the Middle East. ${ }^{2}$ Although a GoogleScholar search for "sports officials in the Middle East" yielded over 20,000 results in just a few seconds, not all were relevant. Indeed, the result of that search reinforces the paucity of research in that area (see Table 1), even with three recent books published on a related subject. ${ }^{3}$

As Reid rightly points out, literature specific to soccer referees is limited within sport sociology. ${ }_{4}$ Predominantly, research concerning soccer referees focuses on the physical demands and motor skills of referees and assistant referees (Krustrup, Mohr, MacDonald, \& Bangsbo, 2004; Mrković, Talović, Jeleškovic, Alić, \& Bajramović, 2009; Reilly \& Gregson, 2006), and decision making and interpretations of the offside rule during a match (Boyko, Boyko, \& Boyko 2007; Catteeuw, Helsen, Gilis, \& Wagemans 2009; de Morais, 2012; Mallo, Frutos, Juárez, \& Navarro 2012). Alternative research projects explore stress management amongst referees, ${ }^{5}$ how referees profile athletes based on race and gender, ${ }^{6}$ career longevity, ${ }^{7}$ violence, abuse, ${ }^{8}$ and game management, often under the overarching theme of referee retention. Quoting prior studies, ${ }^{9}$ Balch and $S \operatorname{cott}{ }^{10}$ reiterate the centrality of the role of sports officials. As these authors point out, "the official is the essential third dimension of an

\section{${ }^{2}$ Kamiel Reid, "The Untold Stories of Women Soccer Referees" (PhD diss., Université} d'Ottawa/University of Ottawa, 2016); Heidi E. Nordstrom, “Behind the Stripes: An Exploration of Female Football Officials' Experiences" (Phd diss., The University of New Mexico, 2013); This study incorporates sports officials from the Middle East including the Arabian Gulf, Iran and Turkey. Indeed, although Iran has been to the FIFA World Cup, football is not the most popular sport in that country. See: http://thescorecard.org/post/384.

${ }^{3}$ Emma Sherry, Nico Schulenkorf, and Pamm Phillips, eds., Managing Sport Development: An International Approach (New York, NY: Routledge, 2016); John Sugden and Alan Thomlinson, Football, Corruption and Lies: Revisiting Badfellas, the Book FIFA Tried to Ban (New York, NY: Routledge, 2017); Giambattista Rossi, Anna Semens, and Jean Francois Brocard, Sports Agents and Labour Markets: Evidence from World Football (New York, NY: Routledge, 2016).

${ }^{4}$ Reid, "The Untold Stories," 26.

${ }^{5}$ Selcuk Gencay, "Magnitude of Psychological Stress Reported by Soccer Referees," Social Behavior and Personality: An International Journal 37, no. 7 (2009): 865-8.

6 Pascal Wagner-Egger, Pascal Gygax, and Farfalla Ribordy. "Racism in Soccer? Perception of Challenges of Black and White Players by White Referees, Soccer Players, and Fans," Perceptual and Motor Skills 114, no. 1 (2012): 275-89; Meân, Lindsey, "Identity and Discursive Practice: Doing Gender on the Football Pitch," Discourse \& Society 12, no. 6 (2001): 789-815.

7Simona Petracovschi, Horea Muresan, and Sorinel Voicu, (2011). "Refereeing and the Perspectives of a Career in Football," Timisoara Physical Education and Rehabilitation Journal 4(7) 16.

${ }^{8}$ Andrea Praschinger, Christine Pomikal, and Stefan Stieger, 2011. "May I Curse a Referee? Swear Words and Consequences," Journal of Sports Science and Medicine 10, 341-345.

${ }^{9}$ For example, Richard Clegg and William A. Thompson, Modern Sports Officiating: A Practical Guide, $5^{\text {th }}$ ed. (Brown \& Benchmark, 1993).

${ }^{10}$ Marcie J. Balch and David Scott, (2007) “Contrary to Popular Belief, Refs are People Too! Personality and Perceptions of Officials," Journal of Sport Behavior 30(1), 3-20. 
athletic contest, with the players and coaches consisting of the first and second dimensions, respectively." 11 Although officials are an important dimension in competition, they have gained little notoriety within the sport institution. ${ }^{12}$

Table 1. Prior Studies on Sports Officials

\begin{tabular}{|c|c|c|}
\hline Author/ Year & Title & Emphasis \\
\hline Balch \& Scott. 2007. & $\begin{array}{l}\text { Contrary to Popular Belief, Refs are People } \\
\text { Too! Personality and Perceptions of Officials. }\end{array}$ & $\begin{array}{l}\text { Personality } \\
\text { and perceptions of } \\
\text { officials }\end{array}$ \\
\hline $\begin{array}{l}\text { Boyko, Boyko \& } \\
\text { Boyko. } 2007 .{ }^{13}\end{array}$ & $\begin{array}{l}\text { Referee Bias Contributes to Home Advantage } \\
\text { in English Premiership Football. }\end{array}$ & Referee bias \\
\hline $\begin{array}{l}\text { Catteeuw, Helsen, } \\
\text { Gilis \& Wagemans. } \\
2009 .\end{array}$ & $\begin{array}{l}\text { Decision-making skills, role specificity, and } \\
\text { deliberate practice in association football } \\
\text { refereeing. }\end{array}$ & $\begin{array}{l}\text { Association football } \\
\text { refereeing }\end{array}$ \\
\hline Colwell. 2000. & $\begin{array}{l}\text { The 'Letter' and the 'Spirit': Football Laws and } \\
\text { Refereeing in the Twenty-First Century. }\end{array}$ & $\begin{array}{l}\text { Football laws and } \\
\text { refereeing }\end{array}$ \\
\hline $\begin{array}{l}\text { Cunningham, } \\
\text { Simmons, } \\
\text { Mascarenhas \& } \\
\text { Redhead. } 2014 .\end{array}$ & $\begin{array}{l}\text { Skilled Interaction: Concepts of } \\
\text { Communication and Player Management in } \\
\text { the Development of Sport Officials. }\end{array}$ & $\begin{array}{l}\text { Development of } \\
\text { sport officials }\end{array}$ \\
\hline $\begin{array}{l}\text { Cuskelly \& Hoye. } \\
2013 .\end{array}$ & Sports Officials' Intention to Continue. & $\begin{array}{l}\text { Sports officials' intention } \\
\text { to continue }\end{array}$ \\
\hline $\begin{array}{l}\text { Forbes, Edwards \& } \\
\text { Fleming. } 2015 .\end{array}$ & $\begin{array}{l}\text { "Women Can't Referee": Exploring } \\
\text { the Experiences of Female Football Officials } \\
\text { within UK Football Culture. }\end{array}$ & $\begin{array}{l}\text { Female football officials } \\
\text { within UK football }\end{array}$ \\
\hline $\begin{array}{l}\text { Forbes \& Livingston. } \\
2013 .\end{array}$ & $\begin{array}{l}\text { Changing the Call: Rethinking Attrition and } \\
\text { Retention in the Ice Hockey Officiating Ranks. }\end{array}$ & $\begin{array}{l}\text { Rethinking attrition and } \\
\text { retention in the ice } \\
\text { hockey officiating }\end{array}$ \\
\hline $\begin{array}{l}\text { Goldsmith \& } \\
\text { Williams.1992. }\end{array}$ & $\begin{array}{l}\text { Perceived Stressors for Football and Volleyball } \\
\text { Officials from Three Rating Levels. }\end{array}$ & $\begin{array}{l}\text { stressors for football and } \\
\text { volleyball officials }\end{array}$ \\
\hline $\begin{array}{l}\text { Petracovschi, } \\
\text { Mureşan, \& Voicu. } \\
2011 .\end{array}$ & $\begin{array}{l}\text { Refereeing and the Perspectives of a Career } \\
\text { in Football. }\end{array}$ & $\begin{array}{l}\text { Refereeing career } \\
\text { in football }\end{array}$ \\
\hline Welford. 2011. & $\begin{array}{l}\text { Tokenism, ties and talking too quietly: } \\
\text { Women's experiences in non-playing football } \\
\text { roles. }\end{array}$ & $\begin{array}{l}\text { Women's experiences in } \\
\text { non-playing football } \\
\text { roles }\end{array}$ \\
\hline $\begin{array}{l}\text { Cleland, Jamie, } \\
\text { Jimmy O'Gorman, \& } \\
\text { Tom Webb. } 2017 .\end{array}$ & $\begin{array}{l}\text { Respect? An investigation into the experience } \\
\text { of referees in association football. }\end{array}$ & $\begin{array}{l}\text { Referee maltreatment in } \\
\text { relation to Respect? }\end{array}$ \\
\hline Tom Webb. 2014. & $\begin{array}{l}\text { The emergence of training and assessment for } \\
\text { referees in Association Football: Moving from } \\
\text { the side-lines. }\end{array}$ & $\begin{array}{l}\text { Training and assessment } \\
\text { for referees }\end{array}$ \\
\hline Tom Webb. 2016. & $\begin{array}{l}\text { Referees and the media: a difficult relationship } \\
\text { but an unavoidable necessity. }\end{array}$ & Referees and the media \\
\hline
\end{tabular}

11 Balch and Scott, 4.

12 Ibid., 28.

${ }^{13}$ Ryan H. Boyko, Adam R. Boyko, and Mark G. Boyko. 2017. "Referee Bias Contributes to Home

Advantage in English Premiership Football," Journal of Sports Sciences 25(11), 1185-1194. 


\begin{tabular}{|c|c|c|}
\hline Tom Webb. 2017. & $\begin{array}{l}\text { Elite refereeing structures in England: a perfect } \\
\text { model or a challenging invention? }\end{array}$ & $\begin{array}{l}\text { Elite refereeing structures } \\
\text { in England }\end{array}$ \\
\hline $\begin{array}{l}\text { Nevill, Alan, Tom } \\
\text { Webb, \& Adam } \\
\text { Watts. } 2013 .\end{array}$ & $\begin{array}{l}\text { Improved training of football referees and the } \\
\text { decline in home advantage post-WW2. }\end{array}$ & $\begin{array}{l}\text { Training of football } \\
\text { referees }\end{array}$ \\
\hline \multicolumn{3}{|l|}{ Books } \\
\hline $\begin{array}{l}\text { Rossi, Semens, \& } \\
\text { Brocard. } 2016 .\end{array}$ & $\begin{array}{l}\text { Sports Agents and Labour Markets: Evidence from } \\
\text { World Football. London, Routledge. }\end{array}$ & $\begin{array}{l}\text { Sports Agents in World } \\
\text { Football }\end{array}$ \\
\hline $\begin{array}{l}\text { Sherry, Schulenkorf } \\
\text { \& Phillips (Eds.) } \\
2016 .\end{array}$ & $\begin{array}{l}\text { Managing Sport Development: An } \\
\text { International Approach. New York, Routledge. }\end{array}$ & $\begin{array}{l}\text { Managing Sport } \\
\text { Development }\end{array}$ \\
\hline $\begin{array}{l}\text { Sugden, John \& } \\
\text { Tomlinson, Alan. } \\
2016 .\end{array}$ & $\begin{array}{l}\text { Football, Corruption and Lies: Revisiting' } \\
\text { Badfellas', the book FIFA tried to ban. New York, } \\
\text { Routledge. }\end{array}$ & Corruption in Football \\
\hline \multicolumn{3}{|l|}{ Theses } \\
\hline $\begin{array}{l}\text { Nordstrom, Heidi E. } \\
2013 .\end{array}$ & $\begin{array}{l}\text { Behind the Stripes: An Exploration of Female } \\
\text { Football Officials' Experiences }\end{array}$ & $\begin{array}{l}\text { Female Football Officials } \\
\text { (Doctoral dissertation). }\end{array}$ \\
\hline Reid, Kamiel. 2016. & The Untold Stories of Women Soccer Referees & $\begin{array}{l}\text { Women Soccer Referees } \\
\text { (Masters dissertation). }\end{array}$ \\
\hline
\end{tabular}

In the light of the discourse on sports officials, Livingston and Forbes highlight that what officials do on the job should be "viewed as equally critical to that of their coaching counterparts in providing structured opportunities for participation within sport. However, officials are often marginalized, and particularly so at the grass roots (or entry) level, where they have been described as the most often forgotten component of the sport system." 14

However, sports officials have been the subject of limited attention in the literaturenot the least those from the Middle East. As one study points out, currently, research regarding athletes, participants, and coaches overshadows research on sports officials. ${ }^{15}$ Forbes and Livingston assert that sports officials are "understudied" and that existing research on sports officials is "limited in scope" and "sorely neglected".${ }^{16}$ Livingston and Forbes found that since the emergence of studies regarding the psychological aspects of sports officiating in the "mid-to-late 1980s and early 1900s," many researchers continue "to examine sundry aspects of the affective (e.g. stress, burnout, and coping behaviours), cognitive (e.g. decision making and perceptual processes) and psychomotor stressors (e.g. fitness requirements, injuries)" through the overarching theme of "stress." 17

In their review of existing literature on sport officials, Balch and Scott observe that there is a great proportion of research on sport officials that focus on stress and burnout. ${ }^{18}$ Specifically, they refer to Taylor et al., ${ }^{19}$ who investigated perceived stress,

\footnotetext{
${ }^{14}$ See Livingston and Forbes, 342.

${ }^{15}$ See Balch \& Scott, “Contrary to Popular Belief, Refs are People Too!”

16 Forbes and Livingston 2016: 343; Forbes and Livingston 2013:295.

${ }^{17}$ Lori A. Livingston \& Susan L. Forbes, "Factors Contributing to the Retention of Canadian Amateur Sport Officials: Motivations, Perceived Organizational Support, and Resilience," International Journal of Sports Science \& Coaching 11, no. 3 (2016): 342-55.

${ }^{18}$ Balch and Scott, "Contrary to Popular Belief, Refs are People Too!"

${ }^{19}$ Adrian H. Taylor, Juri V. Daniel, Larry Leith, \& Ron J. Burke, "Perceived Stress, Psychological

Burnout and Paths to Turnover Intentions among Sport Officials," Journal of Applied Sport

Psychology 2, no. 1 (1990): 84-97.
} 
psychological burnout, and paths to turnover intention, as well as Goldsmith and Williams, ${ }^{20}$ who investigated perceived stressors for sport officials. Overall, researchers ascertain that there are four stress factors that emerge in the study of sport officials: fear of failure/performance concerns; fear of physical harm; interpersonal conflict; and time pressure.

A doctoral thesis reported that, "the greater percentage of research regarding soccer referees is generated in the UK, with studies also coming from institutions in Europe, Australia, and the US." ${ }^{21}$ A sport official is an individual who oversees a sporting contest and administers and enforces the rules. This role encompasses referees, umpires, and judges of all positions, ${ }^{22}$ across a myriad of sports such as basketball, baseball, swimming, and athletics. For example, a given football match may have a referee, two assistant referees, and a fourth official, whereas a baseball game may be overseen by one or more umpires, but all can be classified as sport officials. Sport officials constitute an essential part of sport at all levels of competition. ${ }^{23}$ They have the responsibility of ensuring fair play, enforcing the rules of the game, ensuring that the game functions smoothly, and ensuring the safety of all participants. ${ }^{24}$ In a second doctoral thesis, the responsibilities of the sport official is also clearly articulated as follows: "the role of a sports official is associated with authority, control of others, and power, which are characteristics that are inconsistent with stereotypical feminine roles." ${ }^{25}$ Getting involved in the role has also been highlighted irrespective of gender. "There are various reasons why men and women go into the field of officiating [...] social motivation, interest and enthusiasm for the sport, challenge and excitement, extra money, and lastly the feeling of control generated by officiating." 26

From these quotes, two key observations can be made. The first is that officiating in sports embodies some authority, power, and control, and the second is that motivation varies from an interest in the sport to making money. One can forgive Nordstrom for arguably mistaking the trees for a forest by embarking on a feminist theoretical lens as captured in a series of quotes, one of which cites Boxill, (2006: 116):

Most referees in this study were males, suggesting a need for further investigation of female officials. Concerns about women's physical strength and stamina, have led to strong opposition of females participating in or being employed in physical sports, such as football. Historically, the sport of football has been presented as the "last bastion of male dominance. It is an exclusive 'men's club,' the one place where men can protect what is their own that excludes women." 27

\footnotetext{
${ }^{20}$ Patrick A. Goldsmith \& Jean M. Williams, "Perceived Stressors for Football and Volleyball Officials from Three Rating Levels," Journal of Sport Behavior 15, no. 2 (1992): 106-18.

${ }^{21}$ Reid, 26.

${ }^{22}$ Ian Cunningham, Peter Simmons, Duncan Mascarenhas, \& Steve Redhead, “Skilled Interaction: Concepts of Communication and Player Management in the Development of Sport Officials," International Journal of Sport Communication 7, no. 2 (2014): 166-87.

${ }^{23}$ Balch and Scott, "Contrary to Popular Belief, Refs are People Too!"

${ }^{24}$ Alun D. Ackery, Charles H. Tator, \& Carolyn Snider, "Violence in Canadian Amateur Hockey: The Experience of Referees in Ontario," Clinical Journal of Sport Medicine 22, no. 2 (2012): 86-90.

${ }^{25}$ Nordstrom, 34.

${ }^{26}$ Based on the most common reasons reported by Purdy and Snyder (1985: cf. Nordstrom (2013: 35).

${ }^{27}$ Culled from Nordstrom, 35.
} 
In this study, however, the focus, while being on underrepresentation at the highest level, is gender neutral. Specifically, this study focuses on football referees and swimming judges.

\section{Methodological Considerations}

The methodological contribution of this study is one of storytelling, ${ }^{28}$ and narrative analysis both of which are deemed appropriate for exploratory studies of this nature, as it sets the tone for follow-on studies on the topic and in the rather unexplored context of the Middle East. Using a qualitative methodological approach - a mixture of observational research protocol (including personal and participant observations), ethnography, and nonparticipant observation based on key readings of media clips on sports in the Middle Eastthe main focus is to highlight notable evidence to support the observation that:

The MENA region is witnessing particularly rapid growth, with revenues [...] driven by, among other things, significant investments in sport made by countries within MENA, and in events being staged and hosted across the region. This has resulted in a series of notable developments [...] the International Cricket Council has relocated to Dubai as [it] seeks to become an administrative centre for sport." 29

From a search of the literature on sports officials, only two studies were found to have specifically focused on trends in the Middle East context. The subject of football refereeing has been extensively explored in the context of the UK in a series of papers by Tom Webb and his associates at the University of Portsmouth. ${ }^{30}$ In one of these studies, Webb discusses "an acceptance that the system is now more supportive and the provision of training and relevant experience is providing referees with appropriate grounding in order for these officials to move through the system effectively." 31 He also discusses matters related to professionalism of refereeing and the need for training.

These issues are clearly required in order to have a general understanding and efficacy to deal with crowd influence (especially at home games) and incidences of abuse from both fans and managers. In the context of the former (i.e. crowd influence at home

${ }^{28}$ Elinor Ochs \& Lisa Capps, Living Narrative: Creating Lives in Everyday Storytelling (Cambridge: Harvard University Press; 2009); Yiannis Gabriel, Storytelling in Organizations: Facts, Fictions, and Fantasies (Oxford: University Press, 2000); Thomas P. Oates \& John Pauly, “Sports Journalism as Moral and Ethical Discourse," Journal of Mass Media Ethics 22, no. 4 (2007): 332-47; Oliver Koll, Sylvia Von Wallpach, \& Maria Kreuzer, "Multi-method Research on Consumer-brand Associations: Comparing Free Associations, Storytelling, and Collages," Psychology \& Marketing 27, no. 6 (2010): 584-602; Thomas Horky and Barbara Stelzner. "Sports Reporting and Journalistic Principles," Routledge Handbook of Sport Communication (2013): 118-127.

${ }^{29}$ Cleland, O'Gorman \& Webb, "Respect?"

${ }^{30}$ Alan Nevill, Tom Webb \& Adam Watts, "Improved Training of Football Referees and the Decline in Home Advantage Post-WW2," Psychology of Sport and Exercise 14, no. 2 (2013): 220-7; Tom Webb, "Elite Refereeing Structures in England: A Perfect Model or a Challenging Invention?" Soccer $\mathcal{E}$ Society 18, no.1 (2017): 47-62; Tom Webb, "Referees and the Media: A Difficult Relationship but an Unavoidable Necessity," Soccer \& Society (2016): 1-17; Tom Webb, "The Emergence of Training and Assessment for Referees in Association Football: Moving from the Side-lines," The International Journal of the History of Sport, 31(9), (2014): 1081-97; Jamie Cleland, Jimmy O'Gorman, and Tom Webb, "Respect? An Investigation into the Experience of Referees in Association Football," International Review for the Sociology of Sport (2017).

${ }^{31}$ Webb, “Elite Refereeing Structures in England," Soccer \& Society 18, No. 1 (2017): 57. 
games), Nevill, Webb, and Watts explored the decline of home advantage based on "improved training of football referees." 32 In a study on English and Scottish Professional Football Leagues, they observed and reported that "crowds are known to influence referees' decisions to favour the home side." ${ }^{33}$ Another study, ${ }^{34}$ developed using an online survey, highlights the experiences of football referees officiating since the implementation of a Respect Programme by the English Football Association in 2008. The study reports that about 60 percent of the sampled 2,056 football referees across 51 County Football Associations in England, the Isle of Man, Jersey, and Guernsey experience abuse every couple of games. Undoubtedly, such abuse has had implications as far as coping strategies are concerned.

Deriving insight from the 2015 ICC Cricket World Cup, it can be observed that the landscape of sports business and management is rapidly changing in an environment not known for certain professional sports. Other than Hillel Oscar-umpire and former captain of Israel's national cricket team who died in 2014 after being struck by a cricket ball -there are three notable umpires in the specific context of the UAE, ${ }^{35}$ which is the most established for the region. These are Rabiul Hoque, Akbar Ali, and Iftikhar Ali-originally from Bangladesh, India, and Pakistan, respectively.

Rabiul Hoque is an international cricket umpire from the UAE who was born in Chittagong, Bangladesh on January 1, 1983, and emigrated to the UAE in $2005 .{ }^{36} \mathrm{He}$ stood in his first Twenty20 International (T20I) match between Ireland and the UAE in February 2016. ${ }^{37}$ Akbar Ali is another UAE cricket umpire born in Delhi, India, on March 20, $1973 .{ }^{38} \mathrm{He}$ stood in his first Twenty20 International match between Ireland and the UAE on 16 February 16, 2016. ${ }^{39}$ In October 2016, he was selected as one of the eight umpires to stand in matches in the 2016 ICC World Cricket League Division Four tournament. ${ }^{40}$ He stood in his first One Day International (ODI) match between Scotland and Hong Kong on January 22, 2017.41 Iftikhar Ali (born January 1, 1957, in Sialkot, Pakistan) is an Emirati cricket umpire. ${ }^{42}$ He stood in his first Twenty20 International (T20I) match between Ireland and the UAE on

\footnotetext{
${ }^{32}$ Nevill, Webb \& Watts, "Improved Training of Football Referees," 220.

${ }^{33}$ Ibid.

${ }^{34}$ Cleland, O'Gorman \& Webb, "Respect?"

35 "Israeli Cricket Umpire Dies after being Hit by Ball," The Telegraph, November 29, 2014, www.telegraph.co.uk/news/worldnews/middleeast/israel/11263064/Israeli-cricket-umpire-dies-afterbeing-hit-by-ball.html.

36 "Rabiul Hoque," ESPN Cricinfo, www.espncricinfo.com/ci/content/player/699109.html; Amith Passela, "UAE Umpire Rabiul Hoque has Come a Long Way since Bangladesh Days" The National, retrieved February 2016.

37 "Ireland Tour of United Arab Emirates, 1st T20I: United Arab Emirates v Ireland at Abu Dhabi, Feb 14, 2016," ESPN Cricinfo, retrieved February 14, 2016.

38 "Akbar Ali," ESPN Cricinfo, retrieved February 16, 2016.

39 "Ireland Tour of United Arab Emirates, 2nd T20I: United Arab Emirates v Ireland at Abu Dhabi, Feb 16, 2016," ESPN Cricinfo, retrieved February 16, 2016.

40 “Los Angeles Gets Ready to Host ICC WCL Division 4 Event," International Cricket Council, retrieved October 20, 2016.

41 “United Arab Emirates Tri-Nation Series, 1st Match: Hong Kong v Scotland at Abu Dhabi, Jan 22,

2017," ESPN Cricinfo, retrieved January 22, 2017.

42 "Iftikhar Ali," ESPN Cricinfo, retrieved February 14, 2016.
} 
14 February 2016. ${ }^{43}$ In October 2016, he was selected as one of the eight umpires to stand in matches in the 2016 ICC World Cricket League Division Four tournament. Iftikhar also stood in his first One Day International match between Scotland and Hong Kong on January 22, 2017.44 Following the recognition of Cricket as a key sport in the Middle East - not to mention the selection of Middle East umpires to officiate at the highest level, it is important, however, to restrict the explorations in this study to the top two - the first being football and the other being the Olympic Sport of swimming or aquatics. While the subject of swimming is covered under the framework of the Olympic Games, and more specifically in the context of the Olympic Council of Asia (OCA), which is one of the five continental associations recognized by the International Olympic Committee (IOC) ${ }^{45}$ discussions on football would be more fluid and meta-analytically explored from the Asian Games to the AFC to FIFA World Cup.

\section{Councils, Committees and Competitions}

As one of the five continental associations recognized by the International Olympic Committee (IOC), the Olympic Council of Asia (OCA) was formed in 1982 and has its permanent headquarters in Kuwait. ${ }^{46}$ The OCA is the apex sporting body controlling all the sports in Asia (see Table 2 for a list of sports federations). The main objective of the OCA is to develop sport, culture, and education of Asian youth, as well as to promote international respect, friendship, goodwill, and peace through sports. The Director General of the Executive Work at the OCA headquarters oversees all National Olympic Committees (NOCs) and international affairs under the direct guidance of the OCA President. The OCA Rules Committee met in Tokyo in July 2011 and put forward a bylaw giving the OCA President the right to appoint six members to the Executive Board, which is comprised of three vice presidents and three members. ${ }^{47}$

The National Olympic Committees (NOCs) promote the fundamental principles of Olympism at a national level within the framework of sports. NOCs are committed to the development of athletes and support the development of sport for all programs and highperformance sport in their countries. They also participate in the training of sports administrators by organizing educational programs. ${ }^{48}$ The NOCs also supervise the preliminary selection of potential bid cities. Before a candidate city can compete against those in other countries, it first must win the selection process by the NOC in its own country. The NOC can then name that city to the OCA as a candidate to host the Asian Games. ${ }^{49}$

\footnotetext{
43 "Los Angeles Gets Ready to Host ICC WCL Division 4 Event," October 19, 2016, www.icccricket.com/news/183680.

44 "United Arab Emirates Tri-Nation Series, 1st Match: Hong Kong v Scotland at Abu Dhabi, Jan 22, 2017," ESPN Cricinfo, retrieved January 22, 2017.

${ }^{45}$ See the Official Website at: https://www.olympic.org/the-ioc

${ }^{46}$ www.ocasia.org/Council/Headquaters.aspx.

${ }^{47}$ See OCA Rules Committee meets in Tokyo, 13 July 2011. The OCA Rules Committee Meeting takes place at Grand Prince Hotel New Takanawa on July 13, 2011 in Tokyo, Japan.

${ }^{48}$ As part of the FINA Development Programme, each National Federation may organise one (1) school per discipline -swimming, open water swimming, synchronized swimming, diving or water polo- on an annual basis, www.fina.org/content/officials-schools.

${ }^{49} \mathrm{www}$.ocasia.org/NOCs/Index.aspx.
} 
Table 2. International Sports Federations and their Asian equivalence

\begin{tabular}{|l|l|l|}
\hline Sport & International Federation & Asia Federations \\
\hline Aquatics & AASF & FINA \\
\hline Athletics & AAA & IAAF \\
\hline Basketball & FIBA & FIBA \\
\hline Bodybuilding & AFBF & IFBB \\
\hline Cricket & ACC & ICC \\
\hline Dragon Bat & ADBF & IDBF \\
\hline Football & AFC & FIFA \\
\hline Golf & APGC & IGF \\
\hline Handball & AHF & IHF \\
\hline Judo & JUA & IJF \\
\hline Jujitsu & JJAJ & JJIF \\
\hline Table Tennis & ATTU & ITIF \\
\hline Tennis & ATF & ITF \\
\hline Volleyball & AVC & FIVB \\
\hline Weightlifting & AWF & IWF \\
\hline Wrestling & AAWC & UWW \\
\hline
\end{tabular}

Source: www.ocasia.org/sports/allsportsfed.aspx

Governed by the Asia Swimming Federation (AASF), ${ }^{50}$ under the broader remit of the Fédération Internationale de Natation (FINA), Aquatics or water sports have become quite popular in the region. Aquatics is an interesting case illustration for two reasons. First, it is made up of all sport activities in water - cutting across swimming, diving among others, but all with their own rules and artistry. Synchronized swimming, for example, is one demanding sport that requires "grace, endurance, flexibility, artistry, and exceptional breath control." Second, it is only open to women performing to music within a time limit and underwater speakers to help the competitors when they are underwater to enable them to achieve the split-second timing critical to synchronize swimming. In terms of the officiating, the sport consists of a panel of judges who assess specific moves in a set order, including "boost, rocket, thrusts, and twirls" of competitors. As shown in Table 3, seven countries (arranged in alphabetic order) - i.e., Algeria, Egypt, Jordan, Lebanon, Morocco, Qatar, and Turkey all have five swimming officials each - with Lebanon having three out of five officials as women. In terms of diving, which is performed from a high platform above a pool where divers hit the water with a speed of up to $55 \mathrm{~km} / \mathrm{h}$, Table 4 lists of FINA diving officials from the region.

\footnotetext{
${ }^{50}$ Asia Swimming Federation (AASF) is the area body of the 207-member Federation Internationale de Natation (FINA).
} 
Table 3. FINA Swimming Officials \#19 (1 Jan 2017 - 31 Dec 2020) ${ }^{51}$

\begin{tabular}{|c|c|c|c|c|}
\hline Country & SURNAME & NAME & DOB & Category $^{52}$ \\
\hline Algeria & IKHLEF & Marouane & 28.08 .1983 & $\mathrm{R}$ \\
\hline Algeria & KHELIFI & Mourad & 27.12 .1969 & $\mathrm{R}$ \\
\hline Algeria & KOULIB & Azzedine & 21.01 .1970 & $\mathrm{R}$ \\
\hline Algeria & TALEB AHMED & Mohamed & 12.09 .1992 & $S$ \\
\hline Algeria & YADI & Kamal Nouri & 11.02 .1960 & $\mathrm{~S}$ \\
\hline Egypt & $\begin{array}{l}\text { ABDELLATIF } \\
\text { MOHAMED }\end{array}$ & Rasha Mohamed* & 31.03.1972 & $\mathrm{R}$ \\
\hline Egypt & FATHY & Tharwat Mostafa Mohamed & 01.10 .1988 & $S$ \\
\hline Egypt & $\begin{array}{l}\text { HASSAN } \\
\text { MAHMED }\end{array}$ & Mahmoud Badr & 17.09.1959 & $\mathrm{R}$ \\
\hline Egypt & METAWEA & Ahmed Kamal Hussien & 24.09.1974 & $\mathrm{S}$ \\
\hline Egypt & ROSHDY & Mohamed Refaat Mahmoud & 01.09 .1972 & $\mathrm{R}$ \\
\hline Israel & AVNERRE & Baruch Josef & 19.09.1959 & $\mathrm{R}$ \\
\hline Israel & DIBMAN & Artur & 13.09 .1958 & $\mathrm{R}$ \\
\hline Israel & TALSKY & Mihael & 30.08 .1963 & $S$ \\
\hline Jordan & ABUSHIHAB & Esam Najeh Qassim & 26.02 .1975 & $\mathrm{R}$ \\
\hline Jordan & ALHABAHBEH & Oraib Ayesh Ahmad* & 15.04 .1973 & $S$ \\
\hline Jordan & ALSAWAIR & Ali Mohammad Khalifah & 29.08 .1977 & $S$ \\
\hline Jordan & ALSHARQAWI & Nouraldean Qasem Assad & 20.01 .1969 & $\mathrm{R}$ \\
\hline Jordan & DAKORY & Marwan Hussein & 23.08 .1963 & $\mathrm{R}$ \\
\hline Lebanon & AZAR & Sacha* & 22.12 .1987 & $\mathrm{R}$ \\
\hline Lebanon & BASBOUS & Sandra* & 15.03 .1983 & $S$ \\
\hline Lebanon & DAABOUL & Mohamad & 10.06 .1963 & $\mathrm{R}$ \\
\hline Lebanon & MANSOUR & Ahmad & 29.07 .1978 & $S$ \\
\hline Lebanon & MOUBAYED & Suzane Antoine ${ }^{*}$ & 29.03 .1986 & $\mathrm{R}$ \\
\hline Morocco & EL HAOUAT & Youssef & 07.08 .1964 & $S$ \\
\hline Morocco & EL MOUFTI & Zouheir & 19.01 .1958 & $\mathrm{R}$ \\
\hline Morocco & GUESSOUS & Soufiane & 09.06.1978 & $\mathrm{R}$ \\
\hline Morocco & KOUCHIH & Naima* & 16.05 .1969 & $S$ \\
\hline Morocco & LAKHLALKI & Nour Eddine & 03.11 .1955 & $\mathrm{R}$ \\
\hline Oman & AL AJMI & Ali Hassan Salim & 19.11.1976 & $\mathrm{R}$ \\
\hline Oman & AL ALAWI & $\begin{array}{l}\text { Abdul Monem Khamis } \\
\text { Abddullah }\end{array}$ & 05.10 .1969 & $\mathrm{R}$ \\
\hline Oman & AL BUSAIDI & Hamed Juma Obaid & 23.05 .1977 & $S$ \\
\hline Oman & AL SHAQSI & Hamed Khalfan Salim & 08.06 .1968 & $S$ \\
\hline Oman & AL-DAGHARI & Hilal Mohammed Saayid & 20.05 .1980 & $\mathrm{R}$ \\
\hline Qatar & AL HAMADI & Yousef Abdulla M A & 13.10 .1984 & $\mathrm{R}$ \\
\hline Qatar & ALJABER & Jaber Khalid J M & 02.07 .1991 & $S$ \\
\hline Qatar & ALMAHMOUD & Abdulla Ali A S & 18.09 .1979 & $\mathrm{R}$ \\
\hline Qatar & ALMAHMOUD & Mohammed Ali A S & 11.04 .1993 & $\mathrm{~S}$ \\
\hline Qatar & HUSSAIN & Zainal Abdulla Z A & 21.09 .1983 & $\mathrm{R}$ \\
\hline
\end{tabular}

\footnotetext{
${ }^{51} \mathrm{http}$ //www.fina.org/content/fina-officials-lists.

${ }^{52}$ See the resources for Swimming Officials at https://www.britishswimming.org/browsesport/swimming/officials/[accessed 10 November 2017]
} 
Table 3. Continued.

\begin{tabular}{|l|l|l|l|l|}
\hline Country & SURNAME & NAME & DOB & Category \\
\hline Turkey & AKALIN & Tevfik Cem & 04.03 .1977 & $\mathrm{R}$ \\
\hline Turkey & AYDIN & Ibrahim & 16.02 .1974 & $\mathrm{~S}$ \\
\hline Turkey & ERDEM & Bulent & 15.07 .1957 & $\mathrm{R}$ \\
\hline Turkey & OKUTAN & Hami & 01.01 .1968 & $\mathrm{~S}$ \\
\hline Turkey & OZBAL & Bayram & 01.07 .1959 & $\mathrm{R}$ \\
\hline UAE & AL MESMARI & Rashed Jumah K. B. Al Zari & 28.07 .1984 & $\mathrm{R}$ \\
\hline UAE & ALALEELI & Mohammed Faraj Sulaiman Faraj & 26.01 .1965 & $\mathrm{R}$ \\
\hline
\end{tabular}

*Female Officials

Table 4. FINA Diving Officials 2017

\begin{tabular}{|l|l|l|l|l|}
\hline Country & Last Name & First Name & Date of Birth & $\begin{array}{l}\text { Certified until } \\
\mathbf{3 1 / 1 2} / \mathbf{1 7}\end{array}$ \\
\hline Egypt & ABD EL MAKSOUD & Ahmed & 01.01 .1990 & 2018 \\
\hline Egypt & ABD ELWAHED & Mohamed Ahmed & 20.07 .1975 & 2018 \\
\hline Egypt & $\begin{array}{l}\text { ABDOU ALY MOHMED } \\
\text { ABOUBAKR }\end{array}$ & Nourhan & 23.09 .1992 & 2018 \\
\hline Egypt & ALAA EL DIN & Ahmed & 24.07 .1992 & 2018 \\
\hline Egypt & AWAD & Nessrine Mahmaud & 09.05 .1979 & 2018 \\
\hline Egypt & BEHARY & Ahmed Mohssen & 06.06 .1975 & 2018 \\
\hline Egypt & DARDERY & Ayman Mohamed & 12.07 .1986 & 2018 \\
\hline Egypt & DAW & Yehia & 09.09 .1987 & 2018 \\
\hline Egypt & EL HIELALY & Khaled & 26.05 .1980 & 2018 \\
\hline Egypt & EL MAKABADY & Hoda Kamal & 27.11 .1983 & 2018 \\
\hline Egypt & ELGENDY & Amir Ahmed & 10.07 .1986 & 2018 \\
\hline Egypt & ELHATY HOSNY & Mahmoud & 10.04 .1988 & 2018 \\
\hline Egypt & FARID & Amira & 21.05 .1986 & 2018 \\
\hline Egypt & FEKRY & Asmaa Mohamed & 23.02 .1992 & 2018 \\
\hline Egypt & HANY & Yomna & 12.01 .1988 & 2018 \\
\hline Egypt & HASSAN & Mohammed & 17.08 .1977 & 2018 \\
\hline Egypt & HUSSEIN & Amr Yehia & 01.01 .1984 & 2018 \\
\hline Egypt & KAMEL & Mohamed & 18.07 .1977 & 2018 \\
\hline Egypt & MOHARAM & Doaa Ahmed & 21.06 .1968 & 2018 \\
\hline Egypt & MORGAN & Randa & 15.12 .1975 & 2018 \\
\hline Egypt & MOSTAFA & Omar Mahmoud & 17.01 .1988 & 2018 \\
\hline Egypt & RIZK & Aya Mohamed & 27.08 .1988 & 2018 \\
\hline Egypt & ROSTON & Nabil Ayman & 19.12 .1986 & 2018 \\
\hline Egypt & SADALLAH & Khaled & 03.07 .1962 & 2018 \\
\hline Egypt & SEIFALLAH & Hesham & 03.03 .1969 & 2018 \\
\hline Egypt & WESHAHY & Shaaimaa Ashraf & 19.08 .1988 & 2018 \\
\hline Iran & ARAMI & Mahmoud & 22.05 .1976 & 2017 \\
\hline Iran & HADIGHI & Omid & 08.05 .1971 & 2017 \\
\hline Iran & SHAHBAZ & Shahnazi & 11.07 .1987 & 2018 \\
\hline Kuwait & AL-SAFFAR & *Bashar & 16.04 .1978 & 2017 \\
\hline Kuwait & REDHAEI & Ali & 15.04 .1980 & 2017 \\
\hline Qatar & AL-ADBULJABBAR & A. Rahman & 17.10 .1987 & 2017 \\
\hline Qatar & AL-JANAHI & Abdulaziz & 01.01 .1977 & 2017 \\
\hline Source: FINA Retrved & & & \\
\hline
\end{tabular}

Source: FINA. Retrieved from: http://www.fina.org/content/fina-officials-lists 


\section{The Asian/West Asian Games}

As the biggest multi-sport games after the Olympic Games, the Asian Games is the most prestigious event organized under the framework of the OCA. Like the Olympic Games, the Asian Games are held every four years. The Asian Games follow the sports program of the Olympic Games, with swimming and athletics being the core sports..$^{53}$ The inaugural Asian Games took place in New Delhi, India, in 1951, with eleven countries competing in six sports. The $16^{\text {th }}$ Asian Games in Guangzhou, China, in 2010, featured fortu-five countries and regions competing in forty-two sports, highlighting the growth of the Olympic movement in Asia. The first time the Asian Games was hosted in the Middle East was the $7^{\text {th }}$ Asian Games at the Azadi sports complex in Tehran, Iran, from September 1-16, 1974, ${ }^{54}$ with 3,010 athletes from twenty-five countries (or NOCs), the highest number of participants since the inception of the Games. Fencing, gymnastics, and women's basketball were added to the existing events. In addition to use of state-of-the-art technology, from synthetic tracks to photo-finish cameras, the Games were known for strict security measures due to reported threats from the Palestinians and a Japanese militant sect.

Politics also played a major role. For example, the Arab nations, Pakistan, Taiwan (Republic of China), and North Korea refused to play with Israel in tennis, fencing, basketball, and football. The Asian Games Federation conference, which was held ten months before the Games, decided to expel Taiwan from the games and accepted the entry of the People's Republic of China. These Games were a great success and led to the creation of the West Asian Games Federation (WAGF) based in Kuwait. They are now the organizers who arrange for the Games to be held every four years (Iran in 1997, Kuwait in 2002, and Doha in 2005). Israel and Iran have been the most successful from the Middle East region since inception in 1956, both also hosted the 1964 and 1968 tournaments respectively (see Table 5). The West Asian Games are a smaller multi-sport event, they were first held in Tehran, Iran in 1997.55 The second West Asian Games (Kuwait 2002) were initially expected to be organized in Qatar in 1999 but were cancelled due to unforeseen circumstances. The Games were then expected to be held in Lebanon in 2001 but were also cancelled and relocated to Kuwait. The $2^{\text {nd }}$ West Asian Games ${ }^{56}$ featured 12 countries-Bahrain, Iran, Jordan, Kuwait, Lebanon, Oman, Palestine, Qatar, Syria, Saudi Arabia, United Arab Emirates, and Yemen, across nine sports-Aquatics, Athletics, Basketball, Fencing, Football, Gymnastics, Handball, Karate and Squash. It is worth pointing out two key things here first, Iraq did not participate, and second, there were no women competitions. The $3^{\text {rd }}$ West Asian Games was held in Doha in December 2005, at Qatar Club's Suhaim bin Hamad Stadium. Attracting around 1220 athletes from 13 countries, participating in eleven sports

\footnotetext{
${ }^{53}$ Other events that reflect the diverse sporting culture of the continent include Sepaktakraw (South East Asia), Kabaddi (South Asia) and Wushu (East Asia).

${ }^{54}$ The $1^{\text {st }}$ event took place in Tehran (Iran) in 1974, the $15^{\text {th }}$ Asian Games took place in Doha in 2006, and the 17th edition held in Incheon (north-western South Korea) in 2014. Retrieved from: http://www.ocasia.org/Game/GamesL1.aspx?9QoyD9QEWPeJ2ChZBk5tvA. ${ }^{55}$ Iran deserves some additional commentary. Football is by far one of the most popular sports in Iran but polo and wrestling are more traditional. Other popular sports include skiing, martial arts, basketball, volleyball, and futsal. Futsal is a form of indoor football played by two teams of five. It is played on a hard-court surface delimited by lines and played with a smaller ball with less bounce. ${ }^{56}$ This second event was expected to be held from 20-30 October 2001, but due to armed conflicts in the region, they had to be postponed to 3-12 April 2002.
} 
(see Table 6) - the largest ever in the history of the Games. The eleven events of the $3^{\text {rd }}$ West Asian Games cover swimming, diving, athletics, bowling, fencing, football, track and field, gymnastics (artistic), handball, shooting, volleyball, and weightlifting. ${ }^{57}$

Table 5. AFC Asian Cup 1956-2015

\begin{tabular}{|c|c|c|c|c|c|}
\hline Host & Year & Winner & Second & Third & Fourth \\
\hline Hong Kong & 1956 & South Korea & Israel & Hong Kong & South Vietnam \\
\hline South Korea & 1960 & South Korea & Israel & Taiwan & South Vietnam \\
\hline Israel & 1964 & Israel & India & South Korea & Hong Kong \\
\hline Iran & 1968 & Iran & Burma & Israel & Taiwan \\
\hline Thailand & 1972 & Iran & South Korea & Thailand & Khmer Republic \\
\hline Iran & 1976 & Iran & Kuwait & China & Iraq \\
\hline Kuwait & 1980 & Kuwait & South Korea & Iran & North Korea \\
\hline Singapore & 1984 & KSA & China & Kuwait & Iran \\
\hline Qatar & 1988 & KSA & South Korea & Iran & China \\
\hline Japan & 1992 & Japan & KSA & China & UAE \\
\hline UAE & 1996 & KSA & UAE & Iran & Kuwait \\
\hline Lebanon & 2000 & Japan & KSA & South Korea & China \\
\hline China & 2004 & Japan & China & Iran & Bahrain \\
\hline $\begin{array}{l}\text { Vietnam/ } \\
\text { Indonesia/ } \\
\text { Malaysia/ } \\
\text { Thailand }\end{array}$ & 2007 & Iraq & KSA & South Korea & Japan \\
\hline Qatar & 2011 & Japan & Australia & South Korea & Uzbekistan \\
\hline Australia & 2015 & Australia & South Korea & UAE & Iraq \\
\hline Qatar & 2019 & & & & \\
\hline
\end{tabular}

Source: http://www.myfootballfacts.com/AFCAsiaCupChampionships1956-2011.html

Table 6. West Asian Games Highlights

\begin{tabular}{|l|l|l|}
\hline Host & Year & Highlights \\
\hline Tehran (Iran) & 1997 & $\begin{array}{l}10 \text { countries, 11 sports, no women, 850 athletes and 236 team } \\
\text { officials. }\end{array}$ \\
\hline Kuwait & 2002 & 12 countries, 9 sports, no women. \\
\hline Doha (Qatar) & 2005 & $\begin{array}{l}13 \text { countries, 11 sports, 1220 athletes, first for women, first for } \\
\text { Iraq. }\end{array}$ \\
\hline
\end{tabular}

Women participated for the first time this year and it will also be the first time that Iraq has taken part in the Games (Table 6). The opening ceremony was attended by high profile personalities including the presidents of National Olympic committees, ambassadors, and sports federation presidents. This level of interest underlies the significance of the event including the elements of status elevation, and national prestige of participating countries.

\section{Asian Football Confederation (AFC)}

Football is evidently the most popular sport in the Middle Eastern region, the 2022 FIFA World Cup to be hosted by Qatar is one of the most significant events for the region.

\footnotetext{
${ }^{57}$ http://www.ocasia.org/News/IndexNewsRM.aspx?WKegervtea0EDh4cT4AypA

58 Table 8 shows the top four positions in all the Asian Cup tournaments from 1956 to 2019.
} 
Another important point of consideration has to do with all competitions organized by the Asian Football Confederation (AFC) - the governing body of Asian football and one of the six Confederations making up FIFA. Formed in 1954 in Manila on the side-lines of the second Asian Games, the AFC was sanctioned by FIFA in Berne, Switzerland on June 21 of that year.

The AFC is now headquartered in Kuala Lumpur, Malaysia and consists of 46 Member Associations and one Associate Member Association (The Northern Mariana Islands). Led by the AFC President Shaikh Salman bin Ebrahim Al Khalifa of Bahrain, the AFC launched its Vision and Mission on January 28, 2016 in Doha, Qatar, ${ }^{59}$ setting out its ambitions of being the world's leading Confederation as well as having more successful Asian teams on the world stage and confirming football as the number one sport in the continent. The new Vision and Mission tagline - One Asia, One Goal - signifies the core values of unity professionalism and leadership. In addition to developing and regulating the game, upholding the integrity and laws of the game, boosting grassroots and youth football, and conducting top-level competitions, the AFC also works closely with its Member Associations and key stakeholders to bring to life its objectives under its Vision and Mission. ${ }^{60}$

It is from the need to uphold the integrity and laws of the game that the role of sports officials cannot continue to be taken for granted. Interestingly, beyond players and managers, there have also been some new developments in terms of talent to the Middle East, such as the recent move by Mark Clattenburg. As recently reported in the Guardian, it is hardly on a par with the former England manager Don Revie's defection to the UAE in 1977, but Mark Clattenburg's move to the Middle East has most definitely raised eyebrows. ${ }^{61}$ England's leading referee swapped the Premier League for the Kingdom of Saudi Arabia (KSA), where he replaced Howard Webb as the head of refereeing. Unlike the muchcelebrated Howard Webb, however, Clattenburg, who refereed the Euro 2016 final, is also expected to officiate at matches throughout KSA. The expressed mission of the 41-year-old County Durham-born Clattenburg, was captured in his pronouncement of "himself [being] on an educational mission to improve and professionalise refereeing standards throughout Saudi Arabia." ${ }^{2}$ Clattenburg, meanwhile, was introducing himself to a new public. "My name is Mark Clattenburg ...I was recently voted the best referee in the world [at Dubai's Globe Soccer Awards in December], therefore I bring a wealth of knowledge and a passion for improving refereeing and education here in Saudi Arabia. Clattenburg also described his move to the Middle East in terms an opportunity to educate referees in that region, "I' $\mathrm{m}$ very humbled by this exciting opportunity to support and educate referees, to use my expertise in refereeing some matches and bring referees from other countries around the world to improve the standard here." 63

With two renowned English referees changing batons in the Middle East, the importance of refereeing becomes a topic of discussion for the region. Does the MENA have any established referees? How much do we know about them? How are they perceived by the crowd, players, and coaches? How do they view themselves? All of the above are

\footnotetext{
${ }^{59}$ www.the-afc.com/vision-mission.

${ }^{60}$ Official website of the Asian Football Confederation (AFC). www.the-afc.com/about-afc.

61 Taylor, L. (The Guardian, Thursday 16 February 2017) Retrieved from:

https://www.theguardian.com/football/2017/feb/16/mark-clattenburg-premeir-league-saudi-arabia

62 Ibid.

63 Opcit.
} 
unresolved questions that future research to seek to explore, and address. In this study, however, and as illustrated in Tables 7 and 8, a list of Middle Eastern referees and assistant referees is compiled as drawn-up from the 2011 AFC Asian Cup hosted by Qatar, and the 2016 AFC Under 23 Championship also hosted by Qatar.

Table 7. Referees and Assistant Referees (AFC Asian Cup Qatar 2011)

\begin{tabular}{|l|l|l|}
\hline Name & Country & Designation \\
\hline Nawaf Shukralla & Bahrain & Referee \\
\hline Abdullah Mohamed Al Hilali & Oman & Referee \\
\hline Mohamed Abderrezak Benouza & Algeria & Referee \\
\hline Khalil Al Ghandi & Saudi Arabia & Referee \\
\hline Faghani Alireza & Iran & Referee \\
\hline Abdulrahman Abdou & Qatar & Referee \\
\hline Ali Hamad Albadawi & UAE & Referee \\
\hline Torki Mohsen & Iran & Referee \\
\hline Abdullah Baloushi & Qatar & Referee \\
\hline Saleh Mohamed Al Marzouqi & UAE & Referee \\
\hline Hamed Sulaiman Al Mayahi & Oman & Assistant Referee \\
\hline Khaled Rashed Alallan & Bahrain & Assistant Referee \\
\hline Amine Meknous Mohamed Brahim & Algeria & Assistant Referee \\
\hline Yaser Marad & Kuwait & Assistant Referee \\
\hline Mhd. Jawdat Nehlawi & Syria & Assistant Referee \\
\hline Mohammad Jaber Dharman & Qatar & Assistant Referee \\
\hline Reza Sokhandan & Iran & Assistant Referee \\
\hline Hassan Kamranifar & Iran & Assistant Referee \\
\hline Abedlhak Etchiali & Algeria & Assistant Referee \\
\hline Hassan Rashid Althawadi & Qatar & Assistant Referee \\
\hline
\end{tabular}

Source: Technical Report and Statistics, p. 120-121.

Table 8. List of Referees/ Assistant Referees AFC U23 Championship Qatar 2016

\begin{tabular}{|l|l|}
\hline Category/ Name & Nationality \\
\hline Referees & \\
\hline Beath Christopher James & Australia \\
\hline Ma Ning & China \\
\hline Faghani Alireza Mohammad & Iran \\
\hline Sato Ryuji & Japan \\
\hline Ali Sabah Adday Al-Qaysi & Jordan \\
\hline Adham Mohammad & Jordan \\
\hline Kim Jong Hyeok & Korea \\
\hline Mashentsev Dmitrii & Kyrgyzstan \\
\hline Mohd Amirul Izwan Bin Yaacob & Malaysia \\
\hline Al Kaf Ahmed Abu Bakar Said & Oman \\
\hline Abdulrahman Ibrahim Al Jassim & Qatar \\
\hline Hettikankanamge Dilan Perera & Sri Lanka \\
\hline Almirdasi Fahad Adwan & Saudi Arabia \\
\hline Mohmmed Abdulla Hassan & United Arab Emirates \\
\hline Tantashev Ilgiz & United Arab Emirates \\
\hline
\end{tabular}




\begin{tabular}{|l|l|}
\hline Assistant Referees & \\
\hline Nawaf Shaheen & Bahrain \\
\hline Wang De Xin & China \\
\hline Reza Sokhandan & Iran \\
\hline Yoon Kwangyeol & Korea \\
\hline Talipzhanov Ismailzhan & Kyrgyzstan \\
\hline Ahmad Moannes Nadi Alroalle & Jordan \\
\hline Otsuka Haruhiro & Japan \\
\hline Mohd Yusri bin Muhamad & Malaysia \\
\hline Al Amri Abu Bakar Salim Mahad & Oman \\
\hline Saoud Ahmed Almaqaleh & Qatar \\
\hline Taleb Salem H A Al-Marri & Qatar \\
\hline Deniye GP Parakkrama Hemathunga & Sri Lanka \\
\hline Al Shalwai Abdulah Mutlaq & Saudi Arabia \\
\hline Alabakry Mohammed Maki & Saudi Arabia \\
\hline Hsu Min-Yu & Taiwan (Chinese Taipei) \\
\hline Hasan Mohamed Hasan Abdulla & United Arab Emirates \\
\hline Saidov Jakhongir & Uzbekistan \\
\hline Fahad Jaber Al-Marri (Standby Referee) & Qatar \\
\hline
\end{tabular}

Source: AFC U-23 Refereeing Technical Report 2016

The search for Middle East sports officials of international standing remains an uphill task, especially outside the main sporting countries such as Egypt, Israel, Turkey, and Iran, and the Kingdom of Saudi Arabia (KSA) to a lesser extent. After football, the most popular sports in these countries are arguably aquatics and basketball. ${ }^{64}$ Besides Cricket, the two most popular sports (both by interest and participation) in the Gulf Cooperation Countries (GCC) are football and swimming. ${ }^{65}$ In football, "there is little doubt that the Middle East's best teams are making progress but they are still some way from making a greater impact when it comes to quarter and semi-final stages" of the FIFA World Cup. ${ }^{66}$ Starting the near misses, the Kingdom of Bahrain has been described as having come "within a whisker of reaching the 2006 World Cup, within one goal of beating Trinidad and Tobago in a playoff." 67

Other countries in the Middle East, however, have been more successful than Bahrain. For example, Egypt, Algeria, and Saudi Arabia are the most successful Middle Eastern nations in World Cup finals. Egypt was the first Middle Eastern country to qualify for the World Cup Finals, which they did the second ever tournament in 1934. Egypt can

\footnotetext{
${ }^{64}$ As shown in Table 2, in the case of basketball only four countries (Iran, Jordan, Lebanon and Qatar) from the Middle East fall within the top 50 worldwide - going by the Nike FIBA 2016 World Ranking. Others include UAE, Kuwait, Bahrain, Syria, Palestine and KSA.

${ }^{65}$ It has been observed that key playmakers in the UAE national football team have been linked to transfers to European top sides following the third-place finish at the 2015 AFC Asia Cup in Australia (e.g., Omar Abdulrahman, the UAE talisman, and Mabkhout who scored the opening goal against Japan on Friday 22 January 2015 under 10 minutes). Furthermore, there have been other developments in the sport of Rugby where foreigners (i.e., UAE residents) have now become eligible to adorn the country's shirt and compete in the Hong Kong Asian Under-20s Sevens Rugby tournament in December 2014 (see Sport360, 19 December 2014).

${ }^{66}$ Culled from http://www.myfootballfacts.com/AFCAsiaCupChampionships1956-2011.html. ${ }^{67}$ Ibid.
} 
also lay claim to being the first Middle Eastern country to break into the FIFA Top Ten World rankings, which they did when claiming ninth place, in 2010. However, Algeria have a stronger case for being regarded as the most successful nation from the MENA region at the World Cup finals. The country matched the achievement of KSA by reaching four World Cup finals tournaments, but unlike their Arab counterparts they were not consecutive. ${ }^{68}$

The KSA national team qualified for four consecutive World Cup finals in 1994, 1998, 2002 and 2006. Indeed, it was their debut tournament which produced their best-ever showing. In the opening game in the United States not only did KSA beat seeded Belgium but they did so with a goal that is regarded as one of the greatest ever goals scored on the international stage ${ }^{69}$ Iran ranked first in Asia and $51^{\text {st }}$ in the world rankings as of December 2014. The country, like several others from the region, qualified for four World Cup finals tournaments, but as yet have not progressed beyond the group stages in any of their appearances. ${ }^{70}$ Iraq, although being one of the most "powerful" teams in Asia, has only qualified once for the World Cup finals in 1986 when they lost all three group games scoring only a goal, in the 2-1 loss to another powerhouse - i.e., Belgium.

\section{Conclusions}

The focus of this study has been to explore and highlight the current situation of Middle Eastern sports officials in international sporting events. While the study initially sought to explore and highlight sports officials such as judges, umpires, and referees in those sports where the Middle East countries were active participants, it has not panned out as originally planned. Although a GoogleScholar search for "sports officials in the Middle East" yielded over 20,000 results in just a few seconds, the relevance of the results left a lot to be desired. Indeed, the result of that search reinforces the paucity of research in that area. ${ }^{71}$ As Phillips and Schulenkorf point out, "without officials - umpires or referees - organised sport would not exist." 72 This is because "officials ensure that standard rules of competition

\footnotetext{
${ }^{68}$ But in their debut tournament, in 1982 in Spain, Algeria pulled off one of the greatest shocks in tournament history. A 2-1 win in opening game against reigning European Champions West Germany not only shocked the Germans and world football but also led to perhaps the most, disgraceful episode in FIFA history.

${ }^{69}$ Saudi player Saaed Al-Owairan ran from his own half, fully 70 yards in the 104 degrees that suffocated Washington`s RFK Stadium that day. He bamboozled a posse of Belgian opponents before lifting the ball over Michel Preudhomme, the Belgian keeper, to score the only goal of the game and earn himself immortality. The win took Saudi Arabia into the last 16, where they lost 3-1 to Sweden. It was a feat they have never matched, and a goal that saw Saaed, briefly, hailed as the Maradona of the Arabs.

${ }^{70}$ Iran's only victory, in a final, was the 2-1 victory over the United States, in 1998. Iran`s first World Cup point came from a 1-1 draw with Scotland in their debut match in Argentina in 1978.

${ }^{71}$ Nnamdi O. Madichie. Sharjah Football Club (UAE): still kings? Emerald Emerging Markets Case Studies, 1(4), 1-11, 2011; Nnamdi O. Madichie. Ode to a "million dollar" question: does the future of football lie in the Middle East? Management Decision, 51(9), 1839-1860 (2013); Nnamdi O. Madichie. A celebration of unsung heroes in football: a spotlight on Russia's Leonid Slutski. International Journal of Business \& Applied Sciences, 8(2), 93-120 (2019). http://ijbas.com/wp-content/uploads/2019/07/IJBASSpecial-Issue-Vol.-8-Issue-2.pdf\#page=93

${ }^{72}$ Pamm Phillips and Nico Schulenkorf, "Coaches, Officials and Change Agents in Sport Development," in Managing Sport Development: An International Approach, eds. Emma Sherry, Nico Schulenkorf, Pamm Phillips (Eds.) Managing Sport Development: An International Approach (2016): 111.
} 
are adhered to, and that the sport is played in a safe manner [...] but there has been little attention paid to how [...] officials themselves are developed so that they are effective in SD [sport development] systems."73

If it is accepted that sports officials are central to the success of sports and its development, it is equally important that research on sports also begin to incorporate and consider inclusion of the role of sports officials. More significantly, there is a need to go beyond the psychological wellbeing of sports officials, which happens to be the focus on most research on this group (exploring stress, burnouts, and other anxieties), to more practical matters surrounding training and development to ensure that the vision of most of the sports organisations are met - notably to uphold the rules of the game and ensure its integrity. Generally, good practice examples are highlighted on the AFC website covering a series of workshops and/ or seminars, which require some scholarly attention along three key dimensions (i) further development, (ii) better communicated, and (iii) more robustly translated into tangible research outputs. The following examples of recent initiatives are worth highlighting - the Leaders of World Refereeing gather in Asia for Ground-Breaking Workshop (25 April 2017); ${ }^{74}$ the Seminar for World Cup 2018 qualifiers referees (July 2017); ${ }^{75}$ and the Member Associations' Referee Directors Workshop (25 July 2017). ${ }^{76}$ It is only with these initiatives firmly grounded that any conversation on Middle East officials can begin to make any meaningful sense. Hence these are clearly areas for future research enquiry - what is more? FIFA World Cup 2020 in Qatar is less than two years away.

\footnotetext{
${ }^{73}$ Ibid.

${ }^{74}$ http://www.the-afc.com/referees/leaders-of-world-refereeing-gather-in-asia-for-ground-breakingworkshop

${ }^{75} \mathrm{http}$ ://www.the-afc.com/referees-afc-general-secretary/seminar-for-world-cup-2018-qualifiersreferees-starts

${ }^{76} \mathrm{http}: / / \mathrm{www}$.the-afc.com/referees/ties-strengthen-with-member-associations $\%$ E2\%80\%99-refereedirectors-in-latest-workshop
} 